\title{
Growth and Development Analysis of Group Mexico in the Mining Industry
}

\section{José G Vargas-Hernández ${ }^{*}$}

Lic. Ángel Tomás Wong Dan, University Center for Economic and Managerial Sciences, University of Guadalajara, Periférico Norte 799, Los Belenes, C.P. 45100, Zapopan, Jalisco, México

\begin{abstract}
The aim of this research is to analyze the strategies that have taken Grupo Mexico to be Mexico's largest mining company, the largest copper producer in the country and fourth worldwide. From its founding in 1964, Grupo Mexico has grown at a rapid rate; it is now one of the leading companies in the construction industry, transport and mining. In this paper some theories of industrial organization and microeconomic analysis is used.
\end{abstract}

Keywords: Growth; Mining; Microeconomics; Econometrics; Precious metals

$$
\text { JEL: D21, D24, D43, L10, L11 }
$$

\section{Introduction}

Mining in Mexico has been characterized as one of the most important industries throughout the history of Mexico. Since the days of New Spain to what is today Mexico has always been present in the country's economic activity. The history of Mexican mining is considered in three major stages: The colonization, the Porfiriato and North American crisis of 1929 [1]. The heyday of mining arises from the Porfiriato, when it started with the first mining extractions and minting the coin in Cananea, Sonora. This generated a great economic activity for the country and especially as a source of jobs. In 1929, mining contributed about $10 \%$ of the Gross National Product (GNP), and represented a third of the freight of the railways. From the constitutional changes of 1992, allowed ejidos and mines could be passed to the private sector.

With the implementation of the North America Free Trade Agreement (NAFTA), it was allowed foreign mining companies, especially Canadians appropriated of abandoned mines and potential ejidos for exploitation and mining. The current dominance that Canadian mining companies have in the country has marked the way of doing business in the mining industry. Currently, these mining have more than $70 \%$ of the bids in gold mines in the country. Mexican mining companies have been weakened, and there are only a few who remain within the industry.

This research aims to study the strategies used by Grupo Mexico to enter the mining industry, and use tools of microeconomic analysis to understand how they have affected the strategies of the firm in the current environment. It is very important to study this firm, for its ability to generate employment, contribution to the Mexican mining, production capacity for the country and as a role model.

\section{Definition of the Problem}

Knowing the market structure of the industry will help make this analysis more enriching, help analyze to what structure is Grupo Mexico in different markets of the mining industry and see what it is its role within the industry. As the largest copper producer in the country and has no significant competition in the market makes the structure to be monopolistic, but this is not necessarily the same for other productions such as gold and silver. The market structure of copper production is clearly marked by a single company.

By the end of 2012, Grupo Mexico produced 55\% of the copper in the country. This means that at least half of the production was produced by only one company. Thus, the production of copper has a monopolistic market structure trend. Although this does not mean that in other productions of minerals has marked this trend. Production of gold and silver had only a participation of $3 \%$ and $8 \%$, respectively [2]. But with the production capacity of the company and also it represents the most important mining country; what strategies could take Grupo Mexico to have a more dominant role in the production of gold and silver? Grupo Mexico could change the market structure of the production of gold and silver? Based on the above, microeconomic analysis of market structures and simple linear regression model to meet their elasticity will be made.

\section{Background}

First it must be understood what industry is. An industry is a conglomeration of companies engaged in the production of goods and services that have some similarity to each other [3]. For the mining industry, it is a process of using physical and human resources for the extraction of minerals from the soil. The activity of this industry in the country has its origins 200 years ago when it started the independence of Mexico, that with these resources were extracted from soil succeeded in forging the country as it is now [4]. The mining industry has always been known and characterized as one of the most important industries in the country, since it has historical memory, many jobs have left this activity, even had political overtones as the Mexican revolution or independence. One of the first companies founded for this industry was Peñoles in 1887, 50 years after the consummation of independence. Currently Peñoles is the largest producer of silver and gold in the country.

Grupo Mexico was founded in 1942. It started its first activities in construction, becoming one of the most important companies in the country. From 1965 begins to participate in the mining sector by Asarco Group, a company dedicated to the extraction and processing of copper. Grupo Mexico had acquired 51\% of Asarco's rights. The first strategy to start with these activities was the merger or acquisition

*Corresponding author: José G Vargas-Hernández, Lic. Ángel Tomás Wong Dan, University Center for Economic and Managerial Sciences, University of Guadalajara, Periférico Norte 799, Los Belenes, C.P. 45100, Zapopan, Jalisco, México, Tel: +523337703340 Ext. 25685; E-mail: jvargas2006@gmail.com

Received April 29, 2015; Accepted May 25, 2015; Published June 06, 2015

Citation: Vargas-Hernández JG (2015) Growth and Development Analysis of Group Mexico in the Mining Industry. Int J Econ Manag Sci 4: 262 doi:10.4172/21626359.1000262

Copyright: (c) 2015 Vargas-Hernández JG. This is an open-access article distributed under the terms of the Creative Commons Attribution License, which permits unrestricted use, distribution, and reproduction in any medium, provided the original author and source are credited. 
Citation: Vargas-Hernández JG (2015) Growth and Development Analysis of Group Mexico in the Mining Industry. Int J Econ Manag Sci 4: 262. doi:10.4172/21626359.1000262

of property rights ( $\mathrm{M}$ and $\mathrm{A}$ ), which later was to be one of the most productive and successful companies in the country. Thirteen years later, Grupo Mexico first enters the Mexican Stock Exchange as a mining company. It was when it started to grow and expand in major mining areas of the country as in San Luis Potosi, Sonora, Zacatecas and Chihuahua. The great performance that took the company was able to open up the market, through the market for corporate control (F and A) [3].

Since 1998 Grupo Mexico becomes one of the leading producers of copper and silver, thus remaining until today, although it has lost ground in the extraction of silver. Currently, Grupo Mexico is the largest extractor of copper in the country and third worldwide. He is regarded as the largest and most important mining company in the country. Currently, Germán Larrea Mota-Velasco is the chairman of board of directors of Grupo Mexico. He is also considered one of the richest man in the country, ranking third according to Forbes magazine.

The large magnitude and ability that has Grupo Mexico at the national level is of great importance. According to estimates by the Ministry of Economy through ProMéxico, it was expected that by 2014 the growth of mining production in the country is $2.0 \%$ this depending on how important was what did Grupo Mexico. Some of the strategies implemented by Grupo Mexico were vertical integration. Grupo Mexico's history is marked by the use of this strategy. Following here, a picture of the evolution of Grupo Mexico is displayed in Figure 1 above.

It is observed that in the course of time, Grupo Mexico began to grow from its beginnings as a construction company; the strategy of vertical integration that implemented the company acquired the mining railway system. Given that these three industries are closely linked allowed Grupo Mexico a high growth and development. It will be discussed in greater detail in Figure 2 below.

It can be seen how easily the three major industries that handles Grupo Mexico have a clear advantage over other companies. On the issue of mining, Grupo Mexico has competitive advantage over other companies in the transportation of minerals across the country. And in the construction industry, have mineral resources and transport.

In 2012 Grupo Mexico used the strategy of organic growth, which is a growth from the institution itself using its own resources to be leveraged for new customers or other markets [5]. Grupo Mexico plans to expand the Buenavista Del Cobre mine in Sonora, as the mine with the largest reserves of copper in the world. With investment and other growth projects developed in other countries such as Peru and the United States of America, Grupo Mexico estimated increase production at 625,000 tons to achieve a production of 1.4 million tons of copper in 2015 (Figure 3).

\section{Mining in Mexico: gold and silver}

Mexico is a geographically privileged for the development and mining country ranks first worldwide in the production of silver and is within the top 10 producers of gold and other minerals. It is very important to study the mining industry for its great contributions to the country's economy, contributing 4.9 percent to the Gross Domestic Product and generated in 2013 more than 337,000 direct formal jobs and 1.6 million indirect jobs. Mexico as the main producer of silver for its geographical advantage has had positive growth in silver production in the last 15 years, only without including the economic crisis of 20082009 there was a major drop in production (Figure 4).

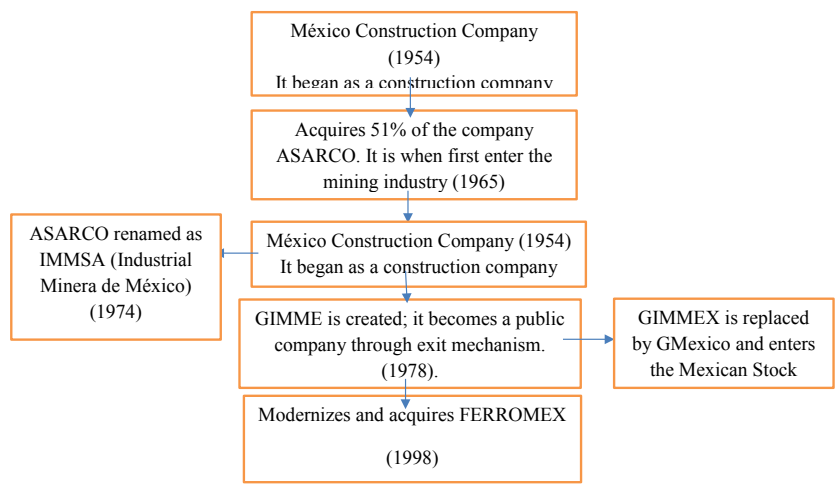

Figure 1: Evolution of Grupo Mexico. Source: Based on data from Grupo Mexico.

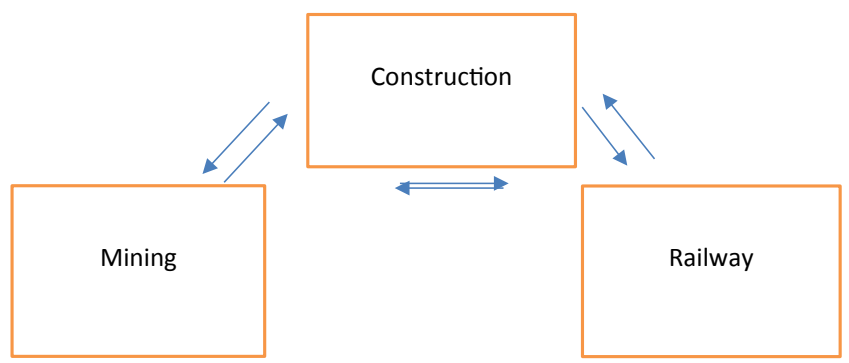

Figure 2: Industrial Interaction Group Mexico. Source: Based on information obtained from Grupo Mexico. 
Citation: Vargas-Hernández JG (2015) Growth and Development Analysis of Group Mexico in the Mining Industry. Int J Econ Manag Sci 4: 262. doi:10.4172/21626359.1000262

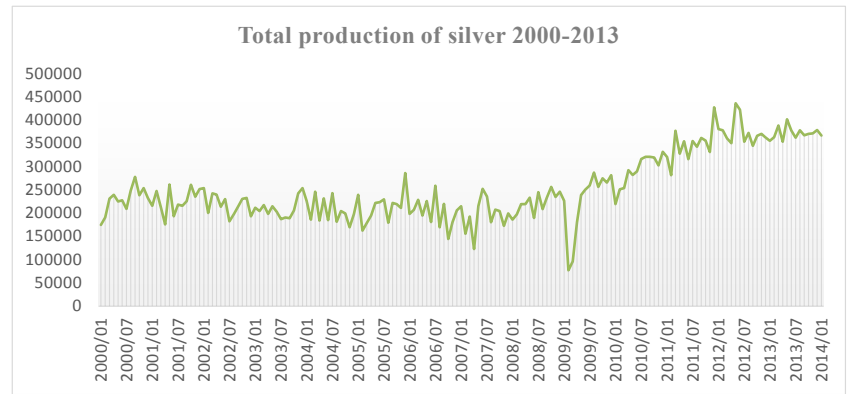

Figure 3: Total domestic production of silver from 2000 to 2013. Source: Data obtained from INEGI (Data in Kg)

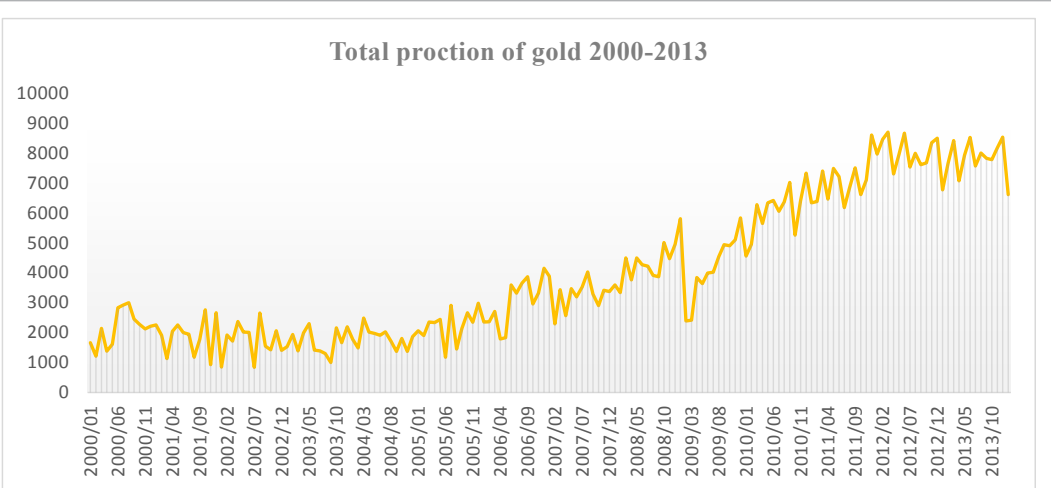

Figure 4: Total domestic production of gold from 2000 to 2013. Source: Data obtained from INEGI (Data in Kg).

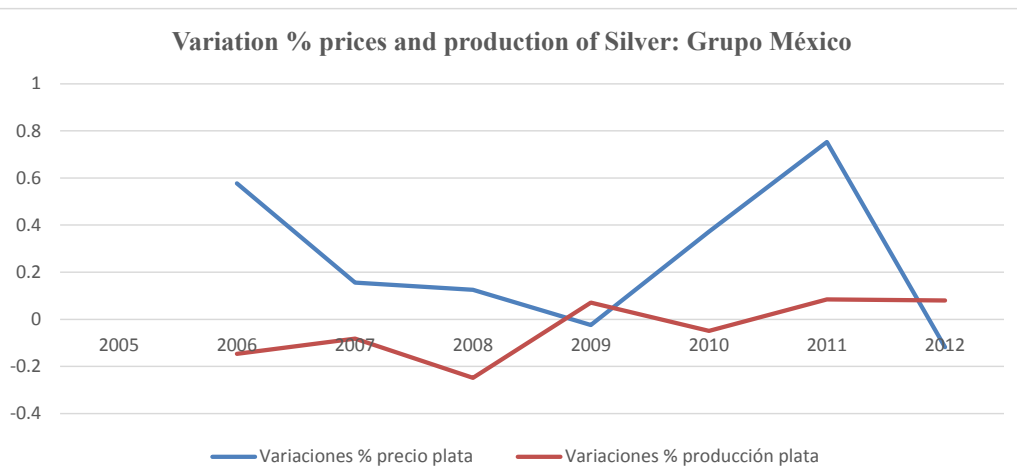

Figure 5: Percentage change in price and production of silver GRPO Mexico. Source: Based on data from INEGI and SONAMI Local-Grupo Mexico.

Although the share of silver production of Grupo Mexico is very little, only $7 \%$ of total production, it is of importance to mark this trend that could change itself, Grupo Mexico takes strategic actions to enter more strongly the silver market. Gold production in Mexico is in ninth place worldwide as a producer of gold. In 2013, Mexico produced $94,216.68$ kilograms, of which 70,585.89 kilograms are produced by only 11 companies established in Mexico.

Of the total silver production there are only 8 companies that control almost $95 \%$ of the silver. The rest are distributed in small mines for gold. The interesting thing about this particular industry is that gold for its natural conditions is relatively scarce. The total amount of gold that exists in Mexico is very little compared with other minerals, and this makes the price to be stable for its production [6]; there are currently 12 companies that control gold production nationwide, of which half are Canadian mining companies. This is due to new policies to attract foreign direct investment and the Free Trade in Latin America of 1994.

\section{Production of gold and silver from Grupo Mexico.}

According to the quarterly reports of Grupo Mexico, the company produces $3 \%$ of silver production and $7 \%$ of gold production because its production strategies have focused more on copper by its geographical location which gave it an advantage, as the Cananea mine, the largest in Latin America. Many of the miners in Mexico have their production depending on market prices. In the opposite case of Grupo Mexico, the price was not a factor in silver production for the company, as its production is relatively low compared to other companies, and also that $84 \%$ of its profits come from copper.

In this graph the percentage changes between the prices of silver and variations \% of silver production compared Grupo Mexico. In 
Citation: Vargas-Hernández JG (2015) Growth and Development Analysis of Group Mexico in the Mining Industry. Int J Econ Manag Sci 4: 262. doi:10.4172/21626359.1000262

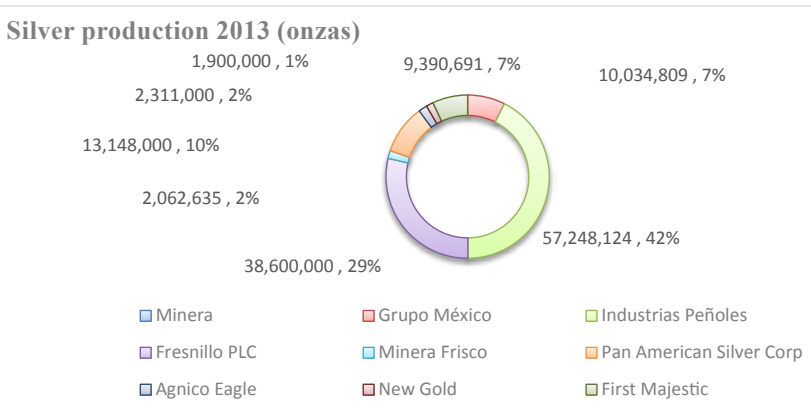

Figure 6: Market share of silver production 2013. Source: Own Calculations with data obtained from the financial reports of those undertakings.

Figure 5, it is shown that silver production of Grupo Mexico did not influence market prices. That is, that while prices are low or high, silver production will continue. Since 2009 the company had an almost constant production. It is a demonstration of how natural resources are scarce in the case of silver and gold production does not depend much the established price.

\section{Analysis Tools}

In this research are used analysis tools of market concentration and dominance, which will determine what type of market structure production of gold and silver. Besides a simple econometric model was used to analyze what kind of elasticity's have the use of capital and labor in the mining of gold and silver. Based on this analysis, it may help in creating strategies to improve resource use production.

\section{Concentration Herfindal and Hirschmann Index}

The Concentration Herfindal and Hirschmann index (HHI) shows the concentration of market participants. That is, that the greater number of participants in a market, the HHI will be smaller. If there are fewer participants in the market, the HHI would be higher. This index helps us to observe the market structure. From $0-1$, where 0 is perfect competition and 1 is monopoly.

$$
\begin{aligned}
& \text { Formula: } \\
& V T=\sum_{i=1}^{n} x_{i} \\
& H=\sum_{i=1}^{n} P_{i}^{2} \\
& P_{i}=\frac{X_{i}}{V T} \\
& \frac{1}{n} \leq H \leq 1
\end{aligned}
$$

Where:

$P_{i}=$ is the market share

$X_{i}=$ value of the position of the market participant $\mathrm{i}$

$\mathrm{VT}=$ total market value

\section{$\mathrm{H}=$ Herfindal-Hirschmann Index}

\section{Econometric model}

The model is a simple regression data bases using time series, thereby logarithms obtained by the capital-output elasticity and elasticity of output-labor.

STATA program will be handled for the Cobb-Douglas model.

\begin{tabular}{|l|c|}
\hline Gold Mining & Production \\
\hline Grupo Mexico & $1.6 \%$ \\
\hline Peñoles & $28.6 \%$ \\
\hline Goldcorp Mexico & $19.5 \%$ \\
\hline Fresnillo PLC & $17.1 \%$ \\
\hline Minera Frisco & $2.6 \%$ \\
\hline Agnico Eagle & $8.7 \%$ \\
\hline Alamos Gold & $8.0 \%$ \\
\hline New Gold & $5.5 \%$ \\
\hline First Majestic & $0.4 \%$ \\
\hline Argonaut Gold & $5.2 \%$ \\
\hline
\end{tabular}

Source: Prepared financial statements of all companies mentioned 2011-2013. Table 1: Market share 2013 gold.

\begin{tabular}{|l|c|}
\hline Silver mining & Production \\
\hline Grupo México & $7.45 \%$ \\
\hline Industrias Peñoles & $42.50 \%$ \\
\hline Fresnillo PLC & $28.66 \%$ \\
\hline Minera Frisco & $1.53 \%$ \\
\hline Agnico Eagle & $9.76 \%$ \\
\hline Alamos Gold & $1.72 \%$ \\
\hline First Majestic & $1.41 \%$ \\
\hline Argonaut Gold & $6.97 \%$ \\
\hline
\end{tabular}

Source: Prepared financial statements of all companies mentioned 2011-2013. Table 2: Market share silver 2013.

Econometric model $Y=A L^{\alpha} K^{\beta}$

Model expected in Stata: $\ln Y=\ln A+\sigma \ln L+\beta \ln K+u$

Where:

$A=$ the total productivity factor

$\mathrm{L}=$ production factor labor

$\mathrm{K}=$ production factor capital (investment)

$\alpha$ and $\beta$ are the elasticities of the corresponding factor

\section{Results and Analysis}

Based on the following tables, it will be analyzed empirically what is the market structure that might have the industry gold and silver.

\section{Structure and market segmentation}

It can be seen that on both silver and gold the production leader is Peñoles Industries besides being the oldest mining and with the greatest reputation that has made it a corporate market leader [7]. Table 1 shows that gold production companies exist and this could 
Citation: Vargas-Hernández JG (2015) Growth and Development Analysis of Group Mexico in the Mining Industry. Int J Econ Manag Sci 4: 262. doi:10.4172/21626359.1000262

Page 5 of 6

mean that the market could be or tends to perfect competition, while in Table 2 shows that in silver production there are fewer companies and only one company that controls almost $50 \%$ of production, so this indicates that it could be closer to the oligopoly, other than gold.

How would be the market share of the mining gold and silver industry? (Figures 6 and 7)

It is clear graphically that Peñoles dominates the production of gold and silver. It can be seen in Table 3 that the concentration index $\mathrm{HHI}$ is 0.28 for both years, i.e. that there has been no change in market structure from 2012 to 2013 . In addition, the 0.28 says that tends to perfect competition although production of silver almost $50 \%$ has been controlled by Peñoles, but could reach the conclusion that tends to be an oligopoly.
Unlike silver production, in this table can be seen that there are more companies producing gold silver, even when the conditions of scarcity of gold are higher than silver. It can be noted that the IHH, 2012 and 2013 is about 17 and $18 \%$. With silver can be concluded at first instance that is a perfect market competition of gold production (Table 4).

\section{Production function of silver in Grupo Mexico (Cobb- Douglas)}

Through the information provided in financial reports of Grupo Mexico, it was possible to obtain by a simple logarithmic regression for the production function of silver Grupo Mexico (Figure 8).

Although the regression of the coefficients obtained in Stata are

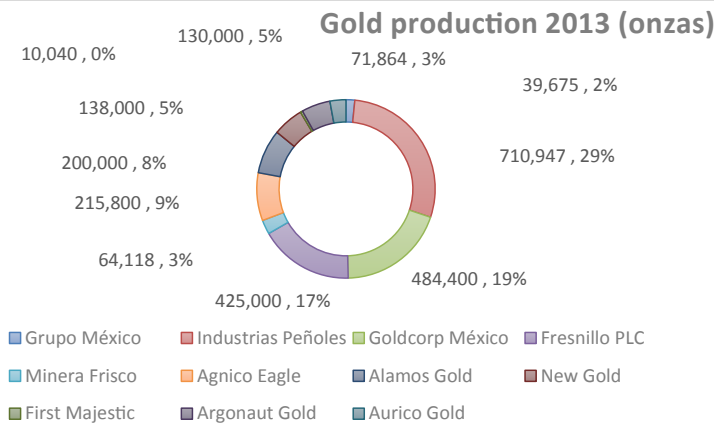

Figure 7: Market share of gold production 2013. Source: Own Calculations with data obtained from the financial reports of those companies.

\begin{tabular}{|c|c|c|c|c|}
\hline Mining & $\begin{array}{l}\text { Participation mining silver } \\
\text { production (\%) } 2013\end{array}$ & $\begin{array}{l}\text { Silver production Participation } \\
\text { (\%) } 2012\end{array}$ & $\begin{array}{l}\text { Square silver production } \\
\text { involving } 2013\end{array}$ & $\begin{array}{l}\text { Square involving silver } \\
\text { production } 2013\end{array}$ \\
\hline Grupo México & $7.45 \%$ & $7.79 \%$ & 0.005550264 & 0.006071671 \\
\hline Industrias Peñoles & $42.50 \%$ & $42.70 \%$ & 0.180641652 & 0.182344074 \\
\hline Fresnillo Plc & $28.66 \%$ & $29.15 \%$ & 0.082123981 & 0.084954423 \\
\hline Minera Frisco & $1.53 \%$ & $1.02 \%$ & 0.000234499 & 0.000103656 \\
\hline $\begin{array}{l}\text { Pan American Silver } \\
\text { Corp }\end{array}$ & $9.76 \%$ & $9.86 \%$ & 0.009528286 & 0.009718959 \\
\hline Agnico Eagle & $1.72 \%$ & $1.91 \%$ & 0.000294371 & 0.00036496 \\
\hline New Gold & $1.41 \%$ & $1.03 \%$ & 0.000198977 & 0.000106017 \\
\hline First Majestic & $6.97 \%$ & $6.54 \%$ & 0.004860607 & 0.004280516 \\
\hline Total & $100 \%$ & $100 \%$ & 0.2834 & 0.2879 \\
\hline
\end{tabular}

Source: Prepared financial statements of all companies mentioned 2011-2013

Table 3: Table of dominance and market concentration plant.

\begin{tabular}{|c|c|c|c|c|}
\hline Mining & $\begin{array}{l}\text { Participation mining silver } \\
\text { production (\%) } 2013\end{array}$ & $\begin{array}{l}\text { Silver production Participation } \\
\text { (\%) } 2012\end{array}$ & $\begin{array}{l}\text { Square of participation of silver } \\
\text { production } 2013\end{array}$ & $\begin{array}{l}\text { Square involving silver } \\
\text { production } 2013\end{array}$ \\
\hline Grupo México & $1.59 \%$ & $1.43 \%$ & 0.000253915 & 0.000204128 \\
\hline Industrias Peñoles & $28.55 \%$ & $30.95 \%$ & 0.081532348 & 0.095760495 \\
\hline Goldcorp México & $19.46 \%$ & $19.36 \%$ & 0.037849847 & 0.037462163 \\
\hline Fresnillo PLC & $17.07 \%$ & $18.57 \%$ & 0.029136254 & 0.034470305 \\
\hline Minera Frisco & $2.58 \%$ & $1.79 \%$ & 0.000663156 & 0.000318785 \\
\hline Agnico Eagle & $8.67 \%$ & $9.22 \%$ & 0.007512055 & 0.00849681 \\
\hline Alamos Gold & $8.03 \%$ & $7.46 \%$ & 0.006452319 & 0.005561988 \\
\hline New Gold & $5.54 \%$ & $4.04 \%$ & 0.003071949 & 0.001634547 \\
\hline First Majestic & $0.40 \%$ & $0.17 \%$ & 1.62601E-05 & 2.74507E-06 \\
\hline Argonaut Gold & $5.22 \%$ & $4.24 \%$ & 0.002726105 & 0.001799789 \\
\hline Aurico Gold & $2.89 \%$ & $2.79 \%$ & 0.000833065 & 0.000779851 \\
\hline Total & $100 \%$ & $100 \%$ & 0.170047273 & 0.186491604 \\
\hline
\end{tabular}

Source: Prepared financial statements of all companies mentioned 2011-2013

Table 4: Index dominance and market concentration of gold. 
Citation: Vargas-Hernández JG (2015) Growth and Development Analysis of Group Mexico in the Mining Industry. Int J Econ Manag Sci 4: 262. doi:10.4172/21626359.1000262

Page 6 of 6

\begin{tabular}{|c|c|c|c|c|c|}
\hline Source & ss & df & Is & & \multirow{3}{*}{$\begin{array}{l}\text { Nurber of dos } \\
\text { FC 2 } \\
\text { Prob }>\text { F 2) } \\
\text { R-squared } \\
\text { Adj R-squared } \\
\text { Root MSE }\end{array}$} \\
\hline $\begin{array}{r}\text { Mode1 } \\
\text { Residual }\end{array}$ & $\begin{array}{l}.002888923 \\
.000858351\end{array}$ & $\begin{array}{ll}2 & .001 \\
2 & .000\end{array}$ & $\begin{array}{l}.001444462 \\
.000429175\end{array}$ & & \\
\hline Total & .003747274 & $4 \quad .000$ & 6819 & & \\
\hline 1production & Coef. & Std. Err. & $t$ & $P>|t|$ & [95\% Conf. Interval] \\
\hline $\begin{array}{r}\text { Tpersonal } \\
\text { Kcapital } \\
\text { _cons }\end{array}$ & $\begin{array}{l}.1923786 \\
.1339541 \\
4.781488\end{array}$ & $\begin{array}{l}.7240215 \\
.5151843 \\
2.081859\end{array}$ & $\begin{array}{l}0.27 \\
0.25 \\
2.30\end{array}$ & $\begin{array}{l}0.815 \\
0.819 \\
0.148\end{array}$ & $\begin{array}{l}-2.922884 \\
-2.082705 \\
-4.176027\end{array}$ \\
\hline
\end{tabular}

Figure 8: Simple linear regression for Cobb-Douglas. Source: Data obtained from financial reports 2006-2012 Grupo Mexico. Regression was developed by program STATA 11.

not statistically significant, for autocorrelation and heteroscedasticity problems since there is a scarcity of data provided by the company through its annual reports, yet it allows seeing the product-labor elasticity and capital-product elasticity.

$$
\begin{aligned}
& \text { Regression Cobb-Douglas } \\
& \ln y=\text { lpersonal }+ \text { lcapital } \\
& \ln y=4.76+0.19 \ln \text { personal }+0.13 \ln \text { capital } \\
& \ln y=4.76 L^{0.19} K^{0.13}
\end{aligned}
$$

It can be seen that although there is not much difference in the elasticity of both factors, the labor factor is a bit more intensive in its use for the production of silver. Perhaps because the investments made for the extraction of silver are lower due to installed capacity for several years.

\section{Conclusions}

It can be concluded that the mining industry is one of the most important in Mexico, for its ability to create jobs, for its historical significance and also represents Mexico as the largest producers of raw materials, in this case precious metals.

It is observed that companies have had more time in the industry are those who have control of productive mineral market because they had the advantage of obtaining bids from the government in advance. Although in the last 10 years such calls started to pass into the hands of Canadian mining. Yet, control over $80 \%$ of the silver is hold by Mexican groups. Different case is the gold case where Canadians have managed to acquire $70 \%$ of the bids and programs of governments in gold mining.

Since 1994 when it was enacted the North American free Trade Agreement (NAFTA), Canadian and American companies have free access to establish in strategic areas for the extraction of precious minerals areas. One of the most important cases was Goldcorp in 2010 who established the Mine Mexico's largest gold mining. Goldcorp launched the Peñasquito Complex in Zacatecas, with an investment of 1,700 million dollars; the mine generates 2,500 direct jobs and 12,000 indirect jobs [8].

Finally, to emphasize that the strategy of organic growth of Grupo Mexico has been successful in recent years, which is a good model for other large companies that want to continue expanding in the market. $84 \%$ of net income of Grupo México was reinvested to continue improving and expanding its productive mines and this has generated higher yields surrendered during these years. Grupo Mexico is definitely a role model.

\section{References}

1. Muro E (2005) La minería mexicana, su evolución, retos y perspectivas. Instituto de Investigaciones Jurídicas, UNAM, 1-48.

2. Grupo México (2013) Reportes financieros. México.

3. Peng M (2012) Estrategia Global. Cengage Learning.

4. Gaytán E, Benita F (2014) La industria minera en México: patrones de desempeño y determinantes de eficiencia. Lecturas de Economía 103-131.

5. Tatum (2005) Cuaderno de opinión: Opciones estratégicas de crecimiento de las entidades financieras españolas. Tatum talento para tu negocio 1-18.

6. Ramón J (2009) El oro como el mejor dinero posible. El oro y la plata, activos monetarios con futuro (1-10) Madrid: Portal Oro.

7. Villafañe J (2001) La reputación corporativa como factor de liderazgo. Área abierta, 1-6.

8. Expansión C (2010) México inaugura mina de oro más grande. CNN Expansión, 1. 